\title{
THE IMPACT OF FINANCIAL LEVERAGE ON FIRM PERFORMANCE: EVIDENCE FROM RUSSIA
}

\author{
Ilyukhin Evgeny, \\ Associate professor, department of economics, \\ management and informatics, \\ The Institute of Aviation Technology and Management \\ of Ulyanovsk State Technical University
}

\begin{abstract}
The relationship between financial leverage and firm performance is studied in this paper. Financial leverage can positively influence firm performance because leverage can be treated as a tool for disciplining management. As such a positive relationship between financial leverage and firm performance is expected based on the agency cost theory. However it is not always applicable to the firms with too high portion of debt. It is because high indebtedness may lead to significant financial limitations and that influences firm performance negatively. A ratio of firm debt to total assets is used as financial leverage measure while return on assets, return on equity and operating margin are employed as firm performance measures. The results for a large sample of Russian joint-stock companies over the period 2004-2013 years show that the impact of financial leverage on Russian firms' performance has been negative. It can be explained by ineffective corporate control of Russian market, debt attracting difficulties, high growth potential and high interest rates for financing through debt. The findings are robust to using different measures of firm performance, checking sub-samples and time clusters and employing alternative estimation approach. The results thus support pecking-order theory but are not consistent with trade-off or free-cash-flow theories.
\end{abstract}

Keywords: financial leverage, firm performance, return on assets, return on equity, operating margin

JEL: E2; E4; G3; G32.

\section{Introduction}

In the case of a perfect market (with no taxes) there is no impact of capital structure on firm value. But if taxes exist firm value can be increased through a change in the capital structure, because of the tax advantage that debt payments bring (Modigliani and Miller, 1958). Also, agency cost and free-cash-flow theories suggest that the capital structure influences firm performance (Jensen and Meckling, 1976; Jensen, 1986). In order to check consistency of these theories, the relationship between financial leverage and firm performance is directly tested in this study.

In theory, a firm benefits from using debt because payments of interest are not taxable and that may lead to increasing firm value. It is known that management tends either to invest free cash in perspective projects or pay dividends to stockholders. However, stockholders try to attract a debt in order to discipline managers through a commitment to existing fixed payments. In addition, banks usually apply financial conditions for firms-borrowers (for example, fixed debt-to-assets ratio). Management is intended to meet these conditions and that may improve firm's efficacy. Another point is that there is an obligation to disclose information about firm activities to debt holders. All this makes management more open to controlling their activities.

A conflict of interest between management and firm's owners arises when managers invest in «meaningless» projects. Firms from different industries with unrelated activities may be acquired by management and that does not affect firm value positively (Blanchard et al, 1994).

Agency costs arise from agency conflict. The agency cost hypothesis suggests that increasing in leverage leads to decreasing in agency costs of debt (Jensen and Meckling, 1976). Therefore, high indebtedness may be connected with better firm performance. It would be achieved via avoiding bankruptcies or a lack of limitations for investments. In order to reduce cash available to management, stockholders may prefer to get dividends. As a result, high dividends are expected from the firms with the managers hired outside (Damodaran, 2010). 
In addition, time lags are expected because an effect of financial leverage on firm performance is unlikely to be immediate. This is one of suggestions supported by the pecking order theory. That means that the past performance affects financial leverage more strongly than the current performance.

Despite of a number of studies devoted to the relationship between financial leverage and firm performance for different countries, there is no unanimity on this question yet.

It is worth to note that there are no works studying the impact of financial leverage on firm performance for Russia. That is why testing an effect of financial leverage on firm performance of Russiabased firms is needed.

Studying a large sample of firms from the same country provides homogeneity of accounting standards that improves correctness of the obtained results. Besides the studied period is wide enough to cover several sub-periods and that also contributes to the results applicability. It is assumed that the results would be similar for all sub-periods.

The study is helpful for investors operating in Russia because optimal debt-to-assets ratio would be obtained. It helps them with identifying over- and underleveraged firms and therefore they may find more perspective investment targets based on this data.

\section{Literature review}

The empirical studies covering the relationship between financial leverage and firm performance are reviewed in this paper. The results seem to be different for developed and developing countries.

For the group of developed countries, the agency cost theory is confirmed for the US firms of banking industry. A parametric measure of profit efficiency was employed in order to measure agency costs for investigating the dualistic relationship between financial leverage and firm performance. The results supported that higher financial leverage and firm performance are bound (Berger et al., 2006). In the case of small firms from New Zealand, agency cost theory is also confirmed. In order to measure firm performance, the distance functions were used in the analysis (Majumdar and Chhibber, 1999). A positive relationship between indebtedness and total factor productivity (TFP) employed as a measure of performance was observed for the United Kingdom (Nickell and Nicolitsas, 1999) while a negative effect was found for Japan (Pushner, 1995) with the same firm performance measure used.

There is a number of studies from developing countries. One of the recent works studied the impact of capital structure on firm performance for a sample of 16.5 thousand Ukrainian firms over the period 2001-2010 years. The study proposes that financial leverage positively affects firm performance through disciplining managers, tax shield and signaling effects. It was found that the relationship between the financial leverage and firm performance measures is negative. These results do not support the free-cash-flow or trade-off theories of capital structure while the validity of the peckingorder theory is confirmed (Iavorskyi, 2013). Another study using a sample of 237 Malaysian listed companies over the period 1995-2011 found that firm performance, which was measured by return on assets, return on equity and earnings per share had a negative relationship with short-, long-term debt and total debt while it was not related to Tobin's Q used as a measure of performance where a significant positive relationship was observed (Salim and Yadav, 2012). A negative relationship between financial leverage and firm performance for other one-country samples was observed for Nigeria (Onaolapo and Kajola, 2010) and India (Majumdar and Chhibber, 1999) with profitability used as performance measure. In the case of 10 developing countries (India, Pakistan, Thailand, Malaysia, Turkey, Zimbabwe, Mexico, Brazil, Jordan, and South Korea), the negative relationship between the financial leverage and firm performance measures was also found (Booth et al., 2001).

Of all available related studies covering Russia, the relationship between financial leverage and firm performance has not been investigated directly. In the study where the relationship between ownership structures and capital structures was explored, it was found that profitability was negatively associated with leverage (Poyry and Maury, 2009). Another work studies the performance effects 
of capital structure, ownership structure choices and corporate governance mechanisms of Russian companies. One of findings related to the subject of this study was that locally owned companies with high management ownership and medium debt level demonstrated high performance before the period of the recent financial crisis (Kokoreva and Stepanova, 2012).

Based on available works relating to the subject, there is no unanimity on the relationship between financial leverage and firm performance. That is the reason why the further research is necessary. Thus, this research contributes to the capital structure theories empirically and the works mentioned above.

\section{Methodology}

Following the previous studies (Berger et al., 2006; Iavorskyi, 2013; Margaritis and Psillaki, 2007), a dynamic model of the relationship between financial leverage and firm performance is proposed. The point is that managers tend to improve business trying to use profit for growth, avoiding dividend payoffs. As such, manager's stakes in firm capital are not expected.

There exist various firm performance measures. It is found that stock returns of firms accumulating debt and repurchasing stocks are stronger while the firms issuing stock and repurchasing debt experience a decline in returns (Smith, 1990). A ratio of firm market capitalization to total assets (Tobin's Q) is used as a firm performance measure indicating both accounting and market values (Mehran, 1995; Morck et al., 1988). A stock price is needed to calculate this measure. It can be applicable to the countries with the well-developed stock markets only (Iavorskyi, 2013). The performance measures calculated with stock prices are unlikely suitable for this study as Russian stock market is not developed fully. It means that stock prices do not reflect information about a firm completely. Besides, there are not enough publicly traded firms to form a sample for getting consistent results. Return on assets (ROA), return on equity (ROE) and EBIT margin would be suitable accounting ratios ignoring the market value of firm (Iavorskyi, 2013; Salim and Yadav, 2012). Some authors suggest using more correct measures of firm performance when accounting ratios could not be employed: total factor productivity (TFP) (Nickell et al., 1997; Nickell and Nicolitsas, 1999). In addition, there are indicators that are specific to the emerging markets: earnings to lagged value of assets and growth in sales (Gibson, 2003). Because of limited available information about operating and financial activities of Russian firms, additional measures of firm performance are not employed in this study.

In order to make results more comparable to the closely-related studies for developing countries, the following variables have been chosen: ROA, ROE, Operating margin (Oper margin). Return on assets and return on equity are calculated as a ratio of net income to book value of assets and equity respectively. Operating margin is calculated as a ratio of operation income to sales.

The variable of financial leverage is calculated as a ratio of total debt to total assets (Michaelas et al., 1999; Rajan and Zingales, 1995). According to the agency cost theory, a positive relationship between financial leverage and firm performance is expected while it is not always applicable to the firms with high portion of debt. It is because high indebtedness may lead to significant financial limitations and that influence firm performance negatively (Berger et al., 2006). In addition, the trade off theory does not suggest linearity between financial leverage and firm performance. The theory assumes impossibility of optimizing a firm value if there is linearity between these measures. In order to check linearity, a squared term of leverage is adopted (Iavorskyi, 2013). Besides, the differentiation between the short- and long-term debt is important because the long-term debt would be considered as a tool for manager's discipline. It is due to fixed payments considered as firm's obligations while short term debt is attracted to finance the current firm operations.

In order to capture time effects, three time clusters have been defined. These are pre-crisis period (2004-2007), crisis period (2008-2009) and post-crisis period (2010-2013). It is assumed that during the first period of an easy access to credit, a number of firms accumulated debt and experienced difficult times in the second one. And during the crisis period the access was limited that made difficult to finance operating activities in the post-crisis period. The results obtained for these periods 
separately may define the relationship between financial leverage and firm performance more correctly.

A firm size is used as a control variable as it affects firm performance directly. It is because of funds available, diversification in operations and controlling managers specific to larger firms (Frank and Goyal, 2003; Himmelberg et al., 1999). However, the larger firm the more difficult to control it and that leads to decreasing management efficiency (Himmelberg et al., 1999; Jayati and Sarkar, 2000). Moreover in the case of the smaller firms, firm owners appear to be firm managers. It helps with avoiding a conflict of interests and related agency costs. The variables $1 n$ Sales and its squared term are adopted as control variables. There are more specific control variables not employed in this study which control for period activity, type of ownership etc.

The main equitation for the model:

$$
\begin{aligned}
& P_{E R F_{i, t}}=\beta_{0}+\beta_{1} D M A N+\beta_{2} D C U S T+\beta_{3} \operatorname{InSALES} S_{i, t}+ \\
& +\beta_{5} L E V_{i, t}+\beta_{6} s q L E V_{i, t}+\varepsilon_{i t}
\end{aligned}
$$

where $P E R F_{i, t}$ - variable of firm performance (ROA, ROE, Oper margin), $L E V_{i, t}$ - leverage, $\ln$ $S A L E S$ - control variable (firm sales), DMAN and DCUST - dummies of manufacturing and wholesale and retail industries respectively.

A positive signs for $\beta_{5}$ and negative one for $\beta_{6}$ are expected (inverse $U$-shaped relationship between financial leverage and firm performance) based on agency cost theory and free-cash-flow hypothesis in particular.

In addition to the model variables, there is a number of other variables influencing firm performance (for example, firm age, ownership structure, corporate governance and R\&D spending). However, it is difficult to control for it as the data is limited. As data panel is unbalanced, the fixed effects that lead to biased results are possible. In order to capture the fixed effects, dummy variables are included into the model and heteroskedasticity issues are addressed.

\section{Data}

The firm-level financial data is used to evaluate the relationship between financial leverage and firm performance. The data (balance sheets, income statements, industry, type of organization) over the period of 2004-2013 years is obtained from Bureau van Dijk's Ruslana dataset. To manage the data effectively, a set of 100,000 firms per year has been downloaded in the order of data provider.

The data on public (open) joint-stock companies and non-public (closed) joint-stock companies are maintained in order to get the homogeneous form of incorporation for a sample. Although only a part of public (open) joint-stock companies prepare reports based on IFRS. It is about $16.5 \%$ of the initial dataset where the main part of enterprises: limited liability companies (LLC), state- and municipal-owned enterprises etc. It is suggested that a data on non-market entities would lead to distortion of the study results while a control for financial reports of LLC is often insufficient in Russia. Therefore, a large sample with consistent data is completed for analysis.

There is a significant portion of observations when a firm in a period has had negative equity value (12,552 obs.). It means firm had an abnormal level of debt compared to equity if an entity has not gone bankrupt. Despite of emerging stage of Russian market, this situation could not be treated as normal. That is the reason for excluding these observations from a sample. Given that activities of finance and insurance firms are different from the firms of other industries, 5,020 observations were excluded from the sample.

In addition, the following outliers (abnormal measures) for the selected variables were excluded:

ROA - 1,191 obs, ROE - 5,909 obs, Oper margin - 1,595 obs.

After data cleaning procedures, about 107000 observations have been obtained.

As only public joint-stock companies prepare their reports using International Financial Reporting 
Standard (IFRS) with a demand to be audited, errors in the whole sample are possible. In the case of employing a large sample, the errors are unlikely significant.

The final dataset is unbalanced because a part of firms does not have observations for whole period of study. The total number of firms per year is shown at Figure 1.

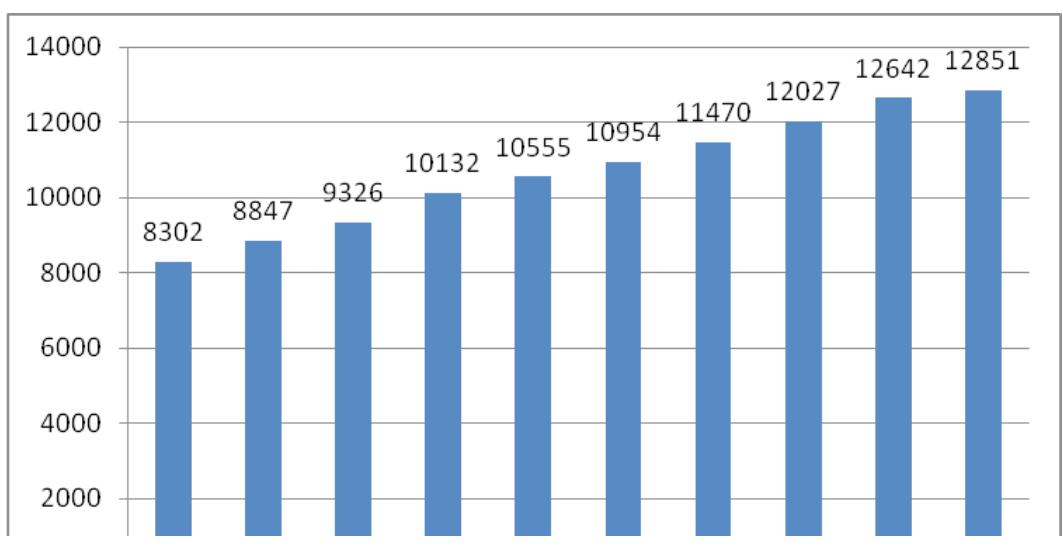

Figure 1: Annual number of firms

In contrary to the previous studies of emerging markets (Caprio and Demirgu, 1998; Iavorskyi, 2013; Schmukler, 2006), it is found that the mean of financial leverage for the sample of Russian join-stock companies equals to 0.566 that is significantly higher. Such a difference can be explained by a highly homogeneous sample that excludes a big block of limited liability companies (LLC). For example, the main part of a sample for Ukraine includes LLC with a lack of debt or a very low portion of it while a sample of joint stock companies that are supposed to attract much more debt is used in this study. On the other hand, Russia-based firms had been operating during the long period of relative stability with easy access to bank loans and commercial credit accompanying sufficient profitability.

The descriptive statistics of the variables included into model is presented in Table 1

Table 1

Summary of descriptive statistic (2004-2013)

\begin{tabular}{|c|c|c|c|c|}
\hline Variable & Mean & Std. Dev. & Min. & Max. \\
\hline LEV & 0.5658 & 0.2827 & 0 & 1 \\
\hline SALES, RUR & $2,697,718$ & $43,586,801$ & 0 & 1 \\
\hline DCUST & 0.1682 & 0.3740 & 0 & 1 \\
\hline DMAN & 0.3488 & 0.4766 & -0.9060 & 0.9738 \\
\hline ROA & 0.0749 & 0.1140 & -1 & 1 \\
\hline ROE & 0.1995 & 0.2794 & -1.9992 & 1 \\
\hline Oper margin & 0.0817 & 0.1454 & 15,000 \\
\hline
\end{tabular}

Figure 2 demonstrates distribution of the dependent variables included into the model. Russia-based firms have positive returns on assets and equity on average with the right-skewed distribution (in the case of return on equity, especially). Operating margin is also the right-skewed and positive. It would mean that Russian firms had positive performance results during the study period.
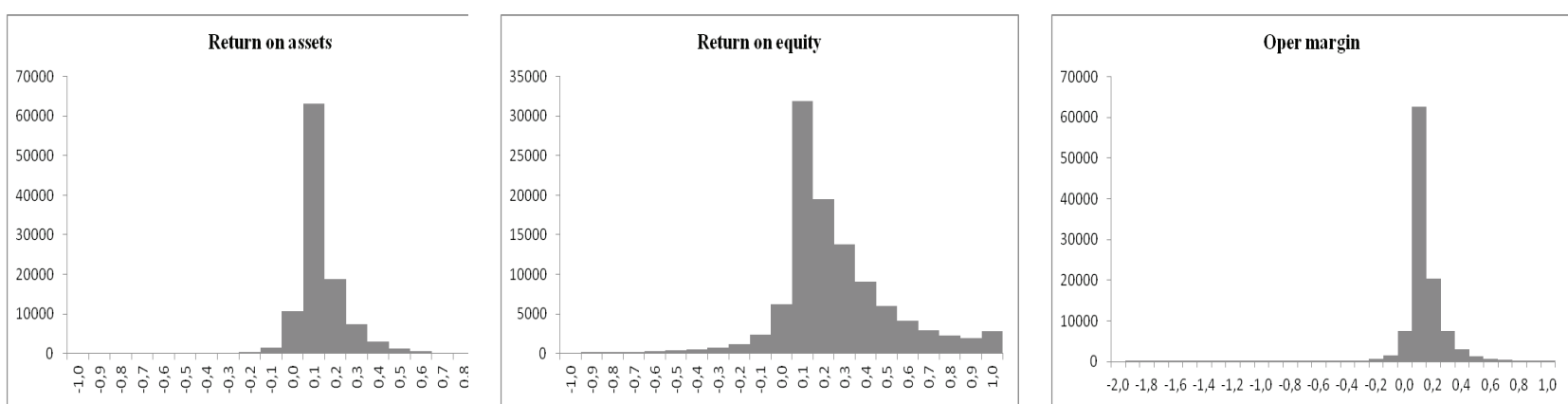

Figure 2: Distribution of dependent variables (return on assets, return on equity, operating margin) 
Given excluding the data, the sample is large enough to neglect incorrect errors. It allows us to make conclusions based on the results obtained from sufficient number of data.

\section{Results}

\section{The results for the whole sample}

Table 2 presents the results for the entire sample. According to the obtained results, an initial hypothesis of the inverted U-shaped relation between financial leverage and firm performance can be rejected. The stable results have been obtained for all firm performance measures. A negative impact of financial leverage on ROA, ROE and Oper margin is observed. This finding can be explained by the fact that the high-growth firms experience a negative effect of leverage on firm performance while it is generally not related to the low-growth firms (McConnell and Servaes, 1995). The projects with positive net present value may be ignored by management as firm's debt is an obligation to fixed payments and it is not the case for the firms with low investment opportunities. The reason to indicating a negative relationship between the financial leverage and firm performance variables would be a huge number of growth opportunities in Russian market that is still developing. Another possible reason is a sensitiveness of results to the different time periods when an increase in debt provoked a decrease in performance for the firms functioning in the period from 2008-2013 years.

Given the specifics of Russian economy, it can be assumed that a part of firms those accounting data is included in the sample, employed the schemes that would lead to attracting debt not used in firm's operating activities (Schneider, 2003). As a result, a firm with debt burden did not have funds to finance its activities that directly affected their performance.

The dualistic nature of impact of firm size (sales) on performance is observed in the case of ROA and ROE used as measures of performance while it is not confirmed for Oper margin.

Table 2

\begin{tabular}{|c|c|c|c|}
\hline \multicolumn{4}{|c|}{ Regression results for the whole sample } \\
\hline & ROA & ROE & Oper Margin \\
\hline const & $\begin{array}{c}0.074 * * * \\
(0.009) \\
\end{array}$ & $\begin{array}{c}0.135^{* * *} * \\
(0.023) \\
\end{array}$ & $\begin{array}{c}0.154 * * * \\
(0.012)\end{array}$ \\
\hline Dman & $\begin{array}{c}-0.010^{* * *} \\
(0.001)\end{array}$ & $\begin{array}{c}-0.037 * * * \\
(0.002)\end{array}$ & $\begin{array}{c}-0.019 * * * \\
(0.001)\end{array}$ \\
\hline Dcust & $\begin{array}{c}0.025^{* * *} \\
(0.001)\end{array}$ & $\begin{array}{c}0.082^{* * *} \\
(0.002)\end{array}$ & $\begin{array}{c}-0.036^{* * *} \\
(0.001) \\
\end{array}$ \\
\hline 1_sales & $\begin{array}{c}0.009 * * * \\
(0.001)\end{array}$ & $\begin{array}{c}0.009^{* * *} * \\
(0.003)\end{array}$ & $\begin{array}{c}-0.009 * * * \\
(0.002)\end{array}$ \\
\hline sq_1_sales & $\begin{array}{c}-0.000^{* * *} \\
(5.182) \\
\end{array}$ & $\begin{array}{c}-0.000^{* *} \\
(0.000) \\
\end{array}$ & $\begin{array}{c}0.001 * * * \\
(6.952) \\
\end{array}$ \\
\hline lev & $\begin{array}{c}-0.107 * * * \\
(0.005)\end{array}$ & $\begin{array}{c}-0.245^{* * *} \\
(0.013) \\
\end{array}$ & $\begin{array}{c}-0.168 * * * \\
(0.007)\end{array}$ \\
\hline sq lev & $\begin{array}{l}-0.050 \\
(0.005) \\
\end{array}$ & $\begin{array}{c}0.341 * * * \\
(0.012) \\
\end{array}$ & $\begin{array}{c}0.061 * * * \\
(0.006)\end{array}$ \\
\hline $\mathrm{N}$ & 107008 & 107003 & 107008 \\
\hline $\mathrm{R}^{2}$ & 0.156 & 0.052 & 0.066 \\
\hline
\end{tabular}

\section{Results for the long-term leverage}

The next stage of the study proposes testing the relationship between the long-term leverage and firm performance. The variable of interest is calculated as a ratio of long-term debt to total assets. A firm attracts the long-term debt to finance investments and capital expenditures while the 
short-term one is used in financing current operations and working capital. According to the freecash theory, the long-term debt makes management more responsible in decision making processes because of existing interest payments.

A U-shaped form of the relationship between the financial leverage and firm performance variables is observed in the case of the long-term leverage. The results presented in Table 3 are similar to the ones for the total firm leverage. However, it is not supported for Oper margin where a coefficient of leverage is not statistically significant.

Table 3

\begin{tabular}{|c|c|c|c|}
\hline \multicolumn{4}{|c|}{ Regression results for the long term leverage } \\
\hline & $\mathrm{ROA}$ & ROE & Oper Margin \\
\hline const & $\begin{array}{c}0.010 \\
(0.009)\end{array}$ & $\begin{array}{c}0.166^{* * *} \\
(0.023)\end{array}$ & $\begin{array}{c}0.083 * * \\
(0.012)\end{array}$ \\
\hline Dman & $\begin{array}{c}-0.007 * * * \\
(0.001)\end{array}$ & $\begin{array}{c}-0.038 * * * \\
(0.002)\end{array}$ & $\begin{array}{c}-0.018 * * * \\
(0.001)\end{array}$ \\
\hline Dcust & $\begin{array}{l}-0.000 \\
(0.001)\end{array}$ & $\begin{array}{c}0.098^{* * *} \\
(0.002)\end{array}$ & $\begin{array}{c}-0.047 * * * \\
(0.001)\end{array}$ \\
\hline 1_sales & $\begin{array}{c}0.008^{* * * *} \\
(0.001)\end{array}$ & $\begin{array}{c}0.003 \\
(0.003)\end{array}$ & $\begin{array}{c}-0.009 * * * \\
(0.002)\end{array}$ \\
\hline sq_1_sales & $\begin{array}{l}-0.000^{*} \\
(5.554)\end{array}$ & $\begin{array}{c}3.974 \\
(0.000)\end{array}$ & $\begin{array}{c}0.001 * * * \\
(7.071)\end{array}$ \\
\hline ltlev & $\begin{array}{c}-0.193 * * * \\
(0.006)\end{array}$ & $\begin{array}{c}-0.404 * * * \\
(0.014)\end{array}$ & $\begin{array}{l}-0.000 \\
(0.007)\end{array}$ \\
\hline sq $\_$ltlev & $\begin{array}{c}0.143^{* * *} \\
(0.009) \\
\end{array}$ & $\begin{array}{c}0.525^{* * *} \\
(0.021)\end{array}$ & $\begin{array}{c}0.115^{* * *} \\
(0.011)\end{array}$ \\
\hline $\mathrm{N}$ & 107008 & 107003 & 107008 \\
\hline $\mathrm{R}^{2}$ & 0.031 & 0.039 & 0.034 \\
\hline
\end{tabular}

Standard errors in parentheses

$* \mathrm{p}<0.10 ; * * \mathrm{p}<0.05 ; * * * \mathrm{p}<0.01$

\section{Results for industry groups and industries}

In order to study the relationship between financial leverage and firm performance in more detail, the whole sample has been divided into several industry sub-samples. Industries are incorporated into twelve industry groups based on the Russian Classification of Economic Activities. An exception is the group of manufacturing industries. This sub-sample provides regression results on industry level. Table 4 presents the regression coefficients for financial leverage and its squared term.

The impact of financial leverage on firm performance is observed for most industry groups. Exceptions (results of weak significance) apply to the following industry groups: hotels and restaurants, health and social work, other community, social and personal service activities. The results for manufacturers of paper and paper products, basic metals, office, accounting and computing machinery, radio, television and communication equipment and apparatus and recycling are often statistically insignificant. Despite of several positive coefficients on significance levels (for example, electricity, gas and water supply or other community, social and personal service activities), the main part of results are similar to the ones for the whole sample. It confirms that an effect of financial leverage on firm performance on industry level is negative.

Table 4

Regression results by industry

\begin{tabular}{|c|c|c|c|c|c|c|c|c|}
\hline \multirow{2}{*}{$\begin{array}{c}\text { Industry } \\
\text { Group }\end{array}$} & \multirow{2}{*}{ Industry } & \multirow{2}{*}{$\begin{array}{c}\text { of } \\
\text { Obs }\end{array}$} & \multicolumn{2}{|c|}{ ROA } & \multicolumn{2}{|c|}{ ROE } & \multicolumn{2}{c|}{ Oper margin } \\
\cline { 3 - 8 } & & lev & sq_lev & lev & sq lev & lev & sq_lev \\
\hline $\begin{array}{c}\text { Agriculture, } \\
\text { hunting and } \\
\text { forestry }\end{array}$ & & 5852 & $\begin{array}{c}-0.169 * * * \\
(0.015)\end{array}$ & $\begin{array}{c}0.030^{*} \\
(0.015)\end{array}$ & $\begin{array}{c}-0.197 * * * \\
(0.037)\end{array}$ & $\begin{array}{c}0.247 * * * \\
(0.037)\end{array}$ & $\begin{array}{c}-0.217 * * * \\
(0.027)\end{array}$ & $\begin{array}{c}0.091 * * * \\
(0.027)\end{array}$ \\
\hline
\end{tabular}




\begin{tabular}{|c|c|c|c|c|c|c|c|c|}
\hline Fishing & & 435 & $\begin{array}{c}-0.526^{* * *} \\
(0.106) \\
\end{array}$ & $\begin{array}{l}0.217^{* *} \\
(0.104)\end{array}$ & $\begin{array}{l}-0.416^{*} \\
(0.237)\end{array}$ & $\begin{array}{c}0.237 \\
(0.232) \\
\end{array}$ & $\begin{array}{c}-0.485^{* * * *} \\
(0 . .133) \\
\end{array}$ & $\begin{array}{l}0.289^{* *} \\
(0.130) \\
\end{array}$ \\
\hline $\begin{array}{l}\text { Mining and } \\
\text { quarrying }\end{array}$ & & 3738 & $\begin{array}{c}-0.310 * * * \\
(0.032)\end{array}$ & $\begin{array}{l}0.083^{* *} \\
(0.032)\end{array}$ & $\begin{array}{c}-0.202 * * * \\
(0.070)\end{array}$ & $\begin{array}{l}0.160^{* *} \\
(0.069)\end{array}$ & $\begin{array}{c}-0.339 * * * \\
(0.046)\end{array}$ & $\begin{array}{c}0.137 * * * \\
(0.046)\end{array}$ \\
\hline \multirow[t]{22}{*}{$\begin{array}{c}\text { Manufacture } \\
\text { of }\end{array}$} & & 37321 & $\begin{array}{c}-0.200^{* * * *} \\
(0.008)\end{array}$ & $\begin{array}{c}0.038^{* * * *} \\
(0.008)\end{array}$ & $\begin{array}{c}-0.293^{* * *} * \\
(0.020)\end{array}$ & $\begin{array}{c}0.307^{* * *} \\
(0.019)\end{array}$ & $\begin{array}{c}-0.178^{* * *} \\
(0.009)\end{array}$ & $\begin{array}{c}0.064^{* * *} * \\
(0.008)\end{array}$ \\
\hline & $\begin{array}{c}\text { food products and } \\
\text { beverages }\end{array}$ & 8811 & $\begin{array}{c}-0.231^{* * * *} \\
(0.014) \\
\end{array}$ & $\begin{array}{c}0.068 * * * \\
(0.013)\end{array}$ & $\begin{array}{c}-0.208^{* * * *} \\
(0.038)\end{array}$ & $\begin{array}{c}0.156^{* * * *} \\
(0.035)\end{array}$ & $\begin{array}{c}-0.116^{* * *} \\
(0.015)\end{array}$ & $\begin{array}{l}0.029 * * \\
(0.014)\end{array}$ \\
\hline & textiles & 663 & $\begin{array}{c}-0.201 * * * \\
(0.057) \\
\end{array}$ & $\begin{array}{c}0.049 \\
(0.053) \\
\end{array}$ & $\begin{array}{c}-0.483^{* * *} \\
(0.141)\end{array}$ & $\begin{array}{c}0.533 * * * \\
(0.132)\end{array}$ & $\begin{array}{c}-0.251^{* * *} \\
(0.068)\end{array}$ & $\begin{array}{l}0.166^{* *} \\
(0.064)\end{array}$ \\
\hline & $\begin{array}{l}\text { wearing apparel; } \\
\text { dressing and } \\
\text { dyeing of fur }\end{array}$ & 511 & $\begin{array}{c}-0.182 * * * \\
(0.070)\end{array}$ & $\begin{array}{c}0.019 \\
(0.068)\end{array}$ & $\begin{array}{l}-0.147 \\
(0.168)\end{array}$ & $\begin{array}{c}0.259 \\
(0.163)\end{array}$ & $\begin{array}{c}-0.253 * * * \\
(0.052)\end{array}$ & $\begin{array}{c}0.130^{* *} \\
(0.051)\end{array}$ \\
\hline & $\begin{array}{l}\text { wood and } \\
\text { products of } \\
\text { wood and cork, } \\
\text { except furniture; } \\
\text { manufacture of } \\
\text { articles of straw } \\
\text { and plaiting } \\
\text { materials }\end{array}$ & 604 & $\begin{array}{c}-0.236 * * * \\
(0.057)\end{array}$ & $\begin{array}{l}0.096^{*} \\
(0.052)\end{array}$ & $\begin{array}{c}-0.642 * * * \\
(0.178)\end{array}$ & $\begin{array}{l}0.706^{* * *} \\
(0.162)\end{array}$ & $\begin{array}{r}-0.160 * \\
(0.087)\end{array}$ & $\begin{array}{c}0.072 \\
(0.079)\end{array}$ \\
\hline & $\begin{array}{l}\text { paper and paper } \\
\text { products }\end{array}$ & 685 & $\begin{array}{c}-0.114 * * \\
(0.054)\end{array}$ & $\begin{array}{l}-0.009 \\
(0.051)\end{array}$ & $\begin{array}{l}-0.170 \\
(0.144)\end{array}$ & $\begin{array}{c}0.183 \\
(0.135)\end{array}$ & $\begin{array}{l}-0.101^{*} \\
(0.059)\end{array}$ & $\begin{array}{l}-0.021 \\
(0.055)\end{array}$ \\
\hline & $\begin{array}{l}\text { publishing, } \\
\text { printing and } \\
\text { reproduction of } \\
\text { recorded media }\end{array}$ & 756 & $\begin{array}{c}-0.394 * * * \\
(0.080)\end{array}$ & $\begin{array}{c}-0.170^{* *} \\
(0.077)\end{array}$ & $\begin{array}{c}-0.498 * * * \\
(0.170)\end{array}$ & $\begin{array}{c}0.484 * * * \\
(0.164)\end{array}$ & $\begin{array}{c}-0.334 * * * \\
(0.061)\end{array}$ & $\begin{array}{c}0.207^{* * * *} \\
(0.059)\end{array}$ \\
\hline & $\begin{array}{l}\text { coke, refined } \\
\text { petroleum } \\
\text { products and } \\
\text { nuclear fuel }\end{array}$ & 508 & $\begin{array}{c}0.019 \\
(0.070)\end{array}$ & $\begin{array}{c}-0.174 * * * \\
(0.067)\end{array}$ & $\begin{array}{l}-0.163 \\
(0.153)\end{array}$ & $\begin{array}{l}0.257^{*} \\
(0.147)\end{array}$ & $\begin{array}{r}-0.184^{*} \\
(0.111)\end{array}$ & $\begin{array}{l}-0.074 \\
(0.107)\end{array}$ \\
\hline & $\begin{array}{c}\text { chemicals and } \\
\text { chemical products }\end{array}$ & 2797 & $\begin{array}{c}-0.313^{* * *} \\
(0.031) \\
\end{array}$ & $\begin{array}{c}-0.102^{* * *} \\
(0.030)\end{array}$ & $\begin{array}{c}0.281^{* * *} \\
(0.068)\end{array}$ & $\begin{array}{c}-0.209 * * * \\
(0.067) \\
\end{array}$ & $\begin{array}{c}-0.241 * * * \\
(0.033)\end{array}$ & $\begin{array}{c}-0.082^{* *} \\
(0.033)\end{array}$ \\
\hline & $\begin{array}{c}\text { rubber and } \\
\text { plastics products }\end{array}$ & 1043 & $\begin{array}{c}-0.154 * * * \\
(0.045)\end{array}$ & $\begin{array}{c}0.030 \\
(0.411)\end{array}$ & $\begin{array}{c}-0.334 * * * \\
(0.122)\end{array}$ & $\begin{array}{c}0.366^{* * * *} \\
(0.112)\end{array}$ & $\begin{array}{c}-0.171 * * * \\
(0.050)\end{array}$ & $\begin{array}{c}0.051 \\
(0.046)\end{array}$ \\
\hline & $\begin{array}{l}\text { other non-metallic } \\
\text { mineral products }\end{array}$ & 3961 & $\begin{array}{c}-0.272^{* * * *} \\
(0.026)\end{array}$ & $\begin{array}{c}0.085^{* * *} * \\
(0.025)\end{array}$ & $\begin{array}{c}-0.338^{* * *} \\
(0.057)\end{array}$ & $\begin{array}{c}0.322^{* * *} \\
(0.056)\end{array}$ & $\begin{array}{c}-0.258^{* * *} \\
(0.025)\end{array}$ & $\begin{array}{l}0.129^{* *} \\
(0.025)\end{array}$ \\
\hline & basic metals & 1447 & $\begin{array}{l}-0.057 \\
(0.040)\end{array}$ & $\begin{array}{c}-0.084^{* *} \\
(0.038)\end{array}$ & $\begin{array}{l}-0.134 \\
(0.109)\end{array}$ & $\begin{array}{c}0.162 \\
(0.103)\end{array}$ & $\begin{array}{l}-0.090^{*} \\
(0.048)\end{array}$ & $\begin{array}{l}-0.019 \\
(0.046)\end{array}$ \\
\hline & $\begin{array}{c}\text { fabricated metal } \\
\text { products, except } \\
\text { machinery and } \\
\text { equipment }\end{array}$ & 2504 & $\begin{array}{c}-0.140^{* * *} \\
(0.032)\end{array}$ & $\begin{array}{l}-0.022 \\
(0.029)\end{array}$ & $\begin{array}{c}-0.395^{* * *} \\
(0.086)\end{array}$ & $\begin{array}{c}0.454 * * * \\
(0.077)\end{array}$ & $\begin{array}{l}-0.026 \\
(0.029)\end{array}$ & $\begin{array}{l}-0.047^{*} \\
(0.026)\end{array}$ \\
\hline & $\begin{array}{c}\text { machinery and } \\
\text { equipment n.e.c. }\end{array}$ & 4670 & $\begin{array}{c}-0.090^{* * * *} \\
(0.023)\end{array}$ & $\begin{array}{l}-0.035^{*} \\
(0.021) \\
\end{array}$ & $\begin{array}{c}-0.347^{* * *} \\
(0.066) \\
\end{array}$ & $\begin{array}{c}0.443 * * * \\
(0.059) \\
\end{array}$ & $\begin{array}{c}-0.114^{* * *} \\
(0.025)\end{array}$ & $\begin{array}{c}0.018 \\
(0.023) \\
\end{array}$ \\
\hline & $\begin{array}{l}\text { office, accounting } \\
\text { and computing } \\
\text { machinery }\end{array}$ & 296 & $\begin{array}{c}-0.210^{*} \\
(0.107)\end{array}$ & $\begin{array}{l}-0.062 \\
(0.094)\end{array}$ & $\begin{array}{l}-0.053 \\
(0.257)\end{array}$ & $\begin{array}{l}(0.076) \\
(0.226)\end{array}$ & $\begin{array}{c}-0.312 * * * \\
(0.102)\end{array}$ & $\begin{array}{c}0.113 \\
(0.089) \\
\end{array}$ \\
\hline & $\begin{array}{c}\text { electrical } \\
\text { machinery and } \\
\text { apparatus n.e.c. }\end{array}$ & 2325 & $\begin{array}{c}-0.111 * * * \\
(0.032)\end{array}$ & $\begin{array}{l}-0.043 \\
(0.029)\end{array}$ & $\begin{array}{c}-0.204 * * \\
(0.084)\end{array}$ & $\begin{array}{c}-0.304 * * * \\
(0.077)\end{array}$ & $\begin{array}{c}-0.169 * * * \\
(0.027)\end{array}$ & $\begin{array}{l}0.046^{*} \\
(0.025)\end{array}$ \\
\hline & $\begin{array}{l}\text { radio, } \\
\text { television and } \\
\text { communication } \\
\text { equipment and } \\
\text { apparatus }\end{array}$ & 881 & $\begin{array}{c}0.078 \\
(0.052)\end{array}$ & $\begin{array}{c}-0.192 * * * \\
(0.051)\end{array}$ & $\begin{array}{c}0.100 \\
(0.122)\end{array}$ & $\begin{array}{l}-0.018 \\
(0.120)\end{array}$ & $\begin{array}{l}-0.063 \\
(0.057)\end{array}$ & $\begin{array}{l}-0.016 \\
(0.056)\end{array}$ \\
\hline & $\begin{array}{c}\text { medical, precision } \\
\text { and optical } \\
\text { instruments, } \\
\text { watches and } \\
\text { clocks }\end{array}$ & 1351 & $\begin{array}{c}-0.161^{* * * *} \\
(0.044)\end{array}$ & $\begin{array}{l}-0.013 \\
(0.043)\end{array}$ & $\begin{array}{c}-0.209 * * \\
(0.103)\end{array}$ & $\begin{array}{c}0.318^{* * *} \\
(0.100)\end{array}$ & $\begin{array}{l}-0.270^{* * *} \\
(0.050)\end{array}$ & $\begin{array}{c}-0.150^{* * * *} \\
(0.049)\end{array}$ \\
\hline & $\begin{array}{c}\text { motor vehicles, } \\
\text { trailers and semi- } \\
\text { trailers }\end{array}$ & 1043 & $\begin{array}{c}0.061 \\
(0.058) \\
\end{array}$ & $\begin{array}{c}-0.172 * * * \\
(0.052)\end{array}$ & $\begin{array}{l}-0.035 \\
(0.166)\end{array}$ & $\begin{array}{c}0.053 \\
(0.145)\end{array}$ & $\begin{array}{c}0.134 * * * \\
(0.047)\end{array}$ & $\begin{array}{c}-0.167 * * * \\
(0.041)\end{array}$ \\
\hline & $\begin{array}{c}\text { other transport } \\
\text { equipment }\end{array}$ & 1329 & $\begin{array}{c}-0.153^{* * *} \\
(0.039)\end{array}$ & $\begin{array}{c}0.034 \\
(0.034)\end{array}$ & $\begin{array}{l}-0.267^{* *} \\
(0.117) \\
\end{array}$ & $\begin{array}{c}0.286^{* * *} \\
(0.103)\end{array}$ & $\begin{array}{c}-0.166^{* *} \\
(0.068) \\
\end{array}$ & $\begin{array}{c}0.057 \\
(0.060)\end{array}$ \\
\hline & $\begin{array}{c}\text { furniture; } \\
\text { manufacturing } \\
\text { n.e.c. }\end{array}$ & 583 & $\begin{array}{c}-0.449 * * * \\
(0.051) \\
\end{array}$ & $\begin{array}{l}0.245 * * * \\
(0.050)\end{array}$ & $\begin{array}{c}-0.267 * * \\
(0.117) \\
\end{array}$ & $\begin{array}{c}0.286 * * * \\
(0.103)\end{array}$ & $\begin{array}{c}-0.166 * * \\
(0.068)\end{array}$ & $\begin{array}{c}0.057 \\
(0.060)\end{array}$ \\
\hline & Recycling & 284 & $\begin{array}{l}-0.131 \\
(0.112) \\
\end{array}$ & $\begin{array}{c}0.038 \\
(0.097) \\
\end{array}$ & $\begin{array}{c}-0.482 \\
(0.306) \\
\end{array}$ & $\begin{array}{l}0.646^{* *} \\
(0.265) \\
\end{array}$ & $\begin{array}{c}0.025 \\
(0.058) \\
\end{array}$ & $\begin{array}{l}-0.041 \\
0.050 \\
\end{array}$ \\
\hline $\begin{array}{l}\text { Electricity, } \\
\text { gas and wa- } \\
\text { ter supply }\end{array}$ & & 5207 & $\begin{array}{c}0.158^{* * *} \\
(0.019)\end{array}$ & $\begin{array}{c}-0.188^{* * *} \\
(0.019)\end{array}$ & $\begin{array}{c}0.081 \\
(0.054) \\
\end{array}$ & $\begin{array}{l}0.121 * * \\
(0.051) \\
\end{array}$ & $\begin{array}{c}-0.115^{* * *} \\
(0.036) \\
\end{array}$ & $\begin{array}{c}0.028 \\
(0.034) \\
\end{array}$ \\
\hline Construction & & 11455 & $\begin{array}{l}-0.015 \\
(0.017)\end{array}$ & $\begin{array}{c}-0.118^{* * *} \\
(0.014)\end{array}$ & $\begin{array}{c}-0.267 * * * \\
(0.052)\end{array}$ & $\begin{array}{c}0.406^{* * *} \\
(0.043)\end{array}$ & $\begin{array}{l}-0.014 \\
(0.022)\end{array}$ & $\begin{array}{c}-0.043^{* *} \\
(0.018) \\
\end{array}$ \\
\hline
\end{tabular}




\begin{tabular}{|c|c|c|c|c|c|c|c|}
\hline $\begin{array}{l}\text { Wholesale } \\
\text { and retail } \\
\text { trade; repair } \\
\text { of motor } \\
\text { vehicles, mo- } \\
\text { torcycles and } \\
\text { personal and } \\
\text { household } \\
\text { goods }\end{array}$ & 17996 & $\begin{array}{c}-0.088^{* * *} * \\
(0.012)\end{array}$ & $\begin{array}{c}-0.108^{* * *} \\
(0.011)\end{array}$ & $\begin{array}{c}-0.248 * * * \\
(0.039)\end{array}$ & $\begin{array}{c}-0.398 * * * \\
(0.032)\end{array}$ & $\begin{array}{c}-0.047 * * * \\
(0.111)\end{array}$ & $\begin{array}{c}-0.025^{* * *} \\
(0.009)\end{array}$ \\
\hline $\begin{array}{l}\text { Hotels and } \\
\text { restaurants }\end{array}$ & 718 & $\begin{array}{c}-0.161^{* *} \\
(0.068)\end{array}$ & $\begin{array}{c}-0.050 \\
0.065\end{array}$ & $\begin{array}{c}0.104 \\
(0.146)\end{array}$ & $\begin{array}{l}-0.203 \\
(0.139)\end{array}$ & $\begin{array}{c}-0.238 * * * \\
(0.091)\end{array}$ & $\begin{array}{c}0.104 \\
(0.087)\end{array}$ \\
\hline $\begin{array}{c}\text { Transport, } \\
\text { storage and } \\
\text { communica- } \\
\text { tions }\end{array}$ & 7449 & $\begin{array}{c}-0.093 * * * \\
(0.021)\end{array}$ & $\begin{array}{c}-0.051^{* *} \\
(0.020)\end{array}$ & $\begin{array}{l}-0.085^{*} \\
(0.048)\end{array}$ & $\begin{array}{c}0.182 * * * \\
(0.046)\end{array}$ & $\begin{array}{c}-0.302^{* * *} \\
(0.034)\end{array}$ & $\begin{array}{c}0.176^{* * *} \\
(0.033)\end{array}$ \\
\hline $\begin{array}{c}\text { Real estate, } \\
\text { renting and } \\
\text { business } \\
\text { activities }\end{array}$ & 14990 & $\begin{array}{l}-0.015 \\
(0.015)\end{array}$ & $\begin{array}{c}-0.133^{* * *} \\
(0.013)\end{array}$ & $\begin{array}{c}-0.091^{* *} \\
(0.036)\end{array}$ & $\begin{array}{c}0.231 * * * \\
(0.032)\end{array}$ & $\begin{array}{l}-0.042^{*} \\
(0.025)\end{array}$ & $\begin{array}{l}-0.030 \\
(0.022)\end{array}$ \\
\hline $\begin{array}{l}\text { Health and } \\
\text { social work }\end{array}$ & 797 & $\begin{array}{c}-0.241 * * * \\
(0.064)\end{array}$ & $\begin{array}{c}0.089 \\
(0.064)\end{array}$ & $\begin{array}{l}-0.066 \\
(0.119)\end{array}$ & $\begin{array}{c}0.108 \\
(0.119)\end{array}$ & $\begin{array}{c}-0.262 * * * \\
(0.069)\end{array}$ & $\begin{array}{c}0.157 * * \\
(0.069)\end{array}$ \\
\hline $\begin{array}{l}\text { Other com- } \\
\text { munity, } \\
\text { social and } \\
\text { personal } \\
\text { service ac- } \\
\text { tivities }\end{array}$ & 929 & $\begin{array}{l}0.123^{*} \\
(0.073)\end{array}$ & $\begin{array}{c}-0.249 * * * \\
(0.070)\end{array}$ & $\begin{array}{c}0.262 * \\
(-0.150)\end{array}$ & $\begin{array}{l}-0.045 \\
(0.144)\end{array}$ & $\begin{array}{c}0.254^{* *} \\
(0.121)\end{array}$ & $\begin{array}{c}-0.207^{*} \\
0.116\end{array}$ \\
\hline
\end{tabular}

Standard errors in parentheses

$* \mathrm{p}<0.10 ; * * \mathrm{p}<0.05 ; * * * \mathrm{p}<0.01$

\section{Results for time clusters (sub-periods)}

The study period includes three sub-periods: economy stabilization (2004-2007), financial crisis (2008-2009) and post-crisis (2010-2013). It would be the case that the firms accumulated a lot of debt during the first sub-period and then experienced difficult times in the second one and the following years after that. That is how increasing in leverage would lead to decreasing in performance. The regression results presented in tables 5,6 and 7 for the clusters show a negative effect of financial leverage on firm performance mainly (statistically significant results for ROE and Oper margin). An exception is ROA as a measure of performance where linearity is observed for all subsamples.

Regression results for I cluster (pre-crisis period: 2004-2007)

\begin{tabular}{|c|c|c|c|}
\hline & ROA & ROE & Oper Margin \\
\hline const & $\begin{array}{c}0.070^{* * *} \\
(0.014)\end{array}$ & $\begin{array}{c}0.085^{* *} \\
(0.196)\end{array}$ & $\begin{array}{c}0.157 * * * \\
(0.018)\end{array}$ \\
\hline Dman & $\begin{array}{c}-0.009^{* * *} \\
(0.001) \\
\end{array}$ & $\begin{array}{l}-0.034 \\
(0.003) \\
\end{array}$ & $\begin{array}{c}-0.012 * * * \\
(0.002) \\
\end{array}$ \\
\hline Dcust & $\begin{array}{c}0.030^{* * *} \\
(0.002) \\
\end{array}$ & $\begin{array}{c}0.090^{* * * *} \\
(0.004)\end{array}$ & $\begin{array}{c}-0.030^{* * *} \\
(0.002)\end{array}$ \\
\hline 1_sales & $\begin{array}{c}0.008^{* * *} \\
(0.002)\end{array}$ & $\begin{array}{l}0.010^{*} \\
(0.005) \\
\end{array}$ & $\begin{array}{c}-0.013 * * * \\
(0.003)\end{array}$ \\
\hline sq_1_sales & $\begin{array}{l}-7.557 \\
(9.553) \\
\end{array}$ & $\begin{array}{l}-3.618^{*} \\
(0.000)\end{array}$ & $\begin{array}{c}0.001 * * * \\
(0.000)\end{array}$ \\
\hline lev & $\begin{array}{c}-0.103^{* * *} \\
(0.009) \\
\end{array}$ & $\begin{array}{c}-0.197 * * * \\
(0.022) \\
\end{array}$ & $\begin{array}{c}-0.165^{* * *} \\
(0.012) \\
\end{array}$ \\
\hline sq_lev & $\begin{array}{c}-0.057 * * * \\
(0.008) \\
\end{array}$ & $\begin{array}{c}0.319 * * * \\
(0.030)\end{array}$ & $\begin{array}{c}0.062 * * * \\
(0.011) \\
\end{array}$ \\
\hline $\mathrm{N}$ & 36606 & 36606 & 36606 \\
\hline $\mathrm{R}^{2}$ & 0.150 & 0.059 & 0.062 \\
\hline
\end{tabular}

Standard errors in parentheses

$* \mathrm{p}<0.10 ; * * \mathrm{p}<0.05 ; * * * \mathrm{p}<0.01$ 
Regression results for II cluster (crisis period: 2008-2009)

\begin{tabular}{|c|c|c|c|}
\hline & ROA & ROE & Oper Margin \\
\hline const & $\begin{array}{c}0.041^{* *} \\
(0.020)\end{array}$ & $\begin{array}{c}0.031 \\
(0.052) \\
\end{array}$ & $\begin{array}{c}0.074 * * * \\
(0.028)\end{array}$ \\
\hline Dman & $\begin{array}{c}-0.013 * * * \\
(0.002)\end{array}$ & $\begin{array}{c}-0.047 * * * \\
(0.004)\end{array}$ & $\begin{array}{c}-0.022 * * * \\
(0.002)\end{array}$ \\
\hline Dcust & $\begin{array}{c}0.025 * * * \\
(0.002)\end{array}$ & $\begin{array}{c}0.076^{* * *} \\
(0.005)\end{array}$ & $\begin{array}{c}-0.040 * * * \\
(0.003)\end{array}$ \\
\hline 1_sales & $\begin{array}{c}0.016 * * * \\
(0.003)\end{array}$ & $\begin{array}{c}0.028 * * * \\
(0.008)\end{array}$ & $\begin{array}{c}0.004 \\
(0.004)\end{array}$ \\
\hline sq_1_sales & $\begin{array}{c}-0.001 * * * \\
(0.000)\end{array}$ & $\begin{array}{c}-0.001 * * * \\
(0.000)\end{array}$ & $\begin{array}{c}0.000 \\
(0.000)\end{array}$ \\
\hline lev & $\begin{array}{c}-0.118^{* * *} \\
(0.011)\end{array}$ & $\begin{array}{c}-0.236^{* * *} \\
(0.030)\end{array}$ & $\begin{array}{c}-0.171 * * * \\
(0.016)\end{array}$ \\
\hline sq_lev & $\begin{array}{c}-0.048^{* * *} \\
(0.010) \\
\end{array}$ & $\begin{array}{c}0.314 * * * \\
(0.027)\end{array}$ & $\begin{array}{c}0.066^{* * *} \\
(0.014) \\
\end{array}$ \\
\hline $\mathrm{N}$ & 21509 & 21509 & 21509 \\
\hline $\mathrm{R}^{2}$ & 0.163 & 0.044 & 0.061 \\
\hline
\end{tabular}

Table 7

Regression results for III cluster (post-crisis period: 2010-2013)

\begin{tabular}{|c|c|c|c|}
\hline & ROA & ROE & Oper Margin \\
\hline const & $\begin{array}{c}0.192 * * * \\
(0.016)\end{array}$ & $\begin{array}{c}0.245^{* * *} \\
(0.043)\end{array}$ & $\begin{array}{c}0.250 * * * \\
(0.021)\end{array}$ \\
\hline Dman & $\begin{array}{c}-0.011^{* * *} \\
(0.001)\end{array}$ & $\begin{array}{c}-0.039 * * * \\
(0.003)\end{array}$ & $\begin{array}{c}-0.024 * * * \\
(0.001)\end{array}$ \\
\hline Dcust & $\begin{array}{c}0.022^{* * *} \\
(0.001) \\
\end{array}$ & $\begin{array}{c}0.082^{* * *} \\
(0.003) \\
\end{array}$ & $\begin{array}{c}-0.038^{* * *} * \\
(0.002)\end{array}$ \\
\hline 1_sales & $\begin{array}{c}0.005^{* *} \\
(0.002)\end{array}$ & $\begin{array}{l}-0.008 \\
(0.006) \\
\end{array}$ & $\begin{array}{c}-0.022 * * * \\
(0.003)\end{array}$ \\
\hline sq 1 _sales & $\begin{array}{l}-6.760 \\
(8.478)\end{array}$ & $\begin{array}{c}0.000 \\
(0.000)\end{array}$ & $\begin{array}{c}0.001 * * * \\
(0.000)\end{array}$ \\
\hline lev & $\begin{array}{c}-0.113^{* * *} \\
(0.007) \\
\end{array}$ & $\begin{array}{c}-0.320 * * * \\
(0.019) \\
\end{array}$ & $\begin{array}{c}-0.178^{* * *} \\
(0.010) \\
\end{array}$ \\
\hline sq_lev & $\begin{array}{c}-0.035^{* * *} \\
(0.006) \\
\end{array}$ & $\begin{array}{c}0.407 * * * \\
(0.017) \\
\end{array}$ & $\begin{array}{c}0.067 * * * \\
(0.009)\end{array}$ \\
\hline $\mathrm{N}$ & 48893 & 48888 & 48893 \\
\hline $\mathrm{R}^{2}$ & 0.159 & 0.059 & 0.076 \\
\hline
\end{tabular}

Standard errors in parentheses

$* \mathrm{p}<0.10 ; * * \mathrm{p}<0.05 ; * * \mathrm{p}<0.01$

\section{Possible endogeneity issues}

An endogeneity analysis with the instrumental variables approach is performed to check the dualistic relationship between financial leverage and firm performance. An average industry leverage and tangibility of assets are employed as instruments. The first instrument is average leverage of all firms in an industry excluding each one firm. This measure is correlated with firm leverage without an effect on firm performance and that creates variability in this variable. Tangibility of assets is employed as collateral measure for leverage (Aivazian, 2005). It means that an increase in leverage is accompanied with increasing tangibility. This instrument is calculated as a ratio of tangible assets to total assets.

Hausman test is employed to test consistency of OLS estimates. In order to test over-identification, Sargan test is used. The null hypothesis is that the proposed instruments are valid (uncorrelated with 
the error term). Finally, testing for weak instruments is conducted. Table 8 presents the estimation results.

Because of high $p$-values in Hausman test, it can be concluded that the OLS estimations are consistent. The $p$-values in Sargan test are large in the case of ROE and Oper margin and the null hypothesis that the over-identifying restrictions are valid can't be rejected. However it is not the case for ROA used as a performance measure. The $F$-value of the weak instruments test shows that the hypothesis that the instruments are weak can be rejected. That means that the instruments are strong.

Table 8

\section{Regression Results with Instrumental Variables Entered}

\begin{tabular}{|c|c|c|c|}
\hline & $\mathrm{ROA}$ & ROE & Oper Margin \\
\hline const & $\begin{array}{c}-0.202 * * * \\
(0.036)\end{array}$ & $\begin{array}{c}-0.675 * * * \\
(0.101)\end{array}$ & $\begin{array}{c}0.281 * * * \\
(0.507)\end{array}$ \\
\hline Dman & $\begin{array}{c}-0.025 * * * \\
(0.002)\end{array}$ & $\begin{array}{c}-0.082 * * * \\
(0.006)\end{array}$ & $\begin{array}{c}-0.012 * * * \\
(0.002)\end{array}$ \\
\hline Dcust & $\begin{array}{c}0.032 * * * \\
(0.002)\end{array}$ & $\begin{array}{c}0.104 * * * \\
(0.005)\end{array}$ & $\begin{array}{c}-0.039 * * * \\
(0.002)\end{array}$ \\
\hline 1_sales & $\begin{array}{c}-0.025 * * * \\
(0.005)\end{array}$ & $\begin{array}{c}-0.092 * * * \\
(0.013)\end{array}$ & $\begin{array}{l}0.007^{*} \\
(0.004)\end{array}$ \\
\hline sq_1_sales & $\begin{array}{c}0.001 * * * \\
(0.000) \\
\end{array}$ & $\begin{array}{c}0.003 * * * \\
(0.000)\end{array}$ & $\begin{array}{l}0.000^{*} \\
(0.000)\end{array}$ \\
\hline lev & $\begin{array}{c}2.421 * * * \\
(0.290)\end{array}$ & $\begin{array}{c}7.156^{* * *} \\
(0.820) \\
\end{array}$ & $\begin{array}{c}-1.329 * * * \\
(0.239)\end{array}$ \\
\hline sq lev & $\begin{array}{c}-2.278 * * * \\
(0.256)\end{array}$ & $\begin{array}{c}-6.183 * * * \\
(0.723)\end{array}$ & $\begin{array}{c}1.085^{* * *} \\
(0.210)\end{array}$ \\
\hline $\mathrm{N}$ & 107008 & 107003 & 107008 \\
\hline $\mathrm{R}^{2}$ & 0.002 & 0.001 & 0.027 \\
\hline $\begin{array}{l}\text { Hausman test } \\
\quad(p \text {-value })\end{array}$ & 2.1557 & 1.5870 & 3.4997 \\
\hline $\begin{array}{c}\text { Sargan test } \\
(p \text {-value })\end{array}$ & 0.0000 & 2.8403 & 4.0993 \\
\hline $\begin{array}{c}\text { First-stage } \\
\mathrm{F}(2,107000)\end{array}$ & 53.8576 & 53.8576 & 53.8576 \\
\hline
\end{tabular}

\section{Conclusions}

The relationship between financial leverage and firm performance is tested using a sample of Russia-based firms. It is shown that the free cash flow theory does not work for debt action in the case of Russian joint-stock companies. Return on assets, return on equity and operation margin used as the performance measures are negatively affected by financial leverage. Such a relationship is rather stable because of the similar results obtained for the long-term debt. Besides, the analysis for the groups of firms on industry level and time clusters (sub-periods) was conducted. The statistically significant results for the industry sub-samples and time clusters also repeated the results for the whole sample with some exceptions. The instrumental variables approach was used in order to access possible endogeneity issues. It is found that OLS estimates are consistent and the employed instruments are strong.

A negative effect of firm indebtedness on firm performance can be explained in the following ways: (1) inefficiency of Russian market for corporate control; (2) difficulties in debt attracting; (3) high growth potential of developing markets; (4) high interest rates specific to financing through debt; (5) shifting profits from the country to offshores; (6) a lack of clear budget limits for management.

The results are similar with the findings for India (Majumdar and Chhibber, 1999), 10 developing countries (Booth, 2001) and Ukraine (Iavorskyi, 2013). 


\section{References}

1. Aivazian V.A., Ying G. and Jiaping, Q. 2005. The impact of leverage on firm investment: Canadian evidence. Journal of Corporate Finance, vol. 11, no. 1, pp. 277-291.

2. Berger A.N. and Bonaccorsi di Patti E. 2006. Capital structure and firm performance: a new approach to testing agency theory and an application to the banking industry. Journal of Banking and Finance, vol. 30, no. 4, pp. 1065-1102.

3. Blanchard O.J., Lopez-de-Silanes F. and Shleifer A. 1994. What do firms do with cash windfalls? Journal of Financial Economics, vol. 36, no. 3, pp. 337-360.

4. Booth L., Aivazian V., Demirguc-Kunt A. and Maksimovic V. 2001. Capital structures in developing countries. The Journal of Finance, vol. 56, no. 1, 87-130.

5. Caprio G. and Demirgü A. 1998. The role of long-term finance: theory and evidence. The World Bank Research Observer, vol. 13, no. 2, 171-189.

6. Damodaran A. 2010. Applied Corporate Finance. 3rd edition. New York, Wiley.

7. Frank M.Z. and Goyal V.K. 2003. Testing the pecking order theory of capital structure. Journal of Financial Economics, vol. 67, no. 2, pp. 217-248.

8. Gibson M.S. 2003. Is corporate governance ineffective in emerging markets? Journal of Financial and Quantitative Analysis, vol. 38, no. 1, pp. 231-250.

9. Himmelberg C.P., Hubbard R.G. and Palia D. 1999. Understanding the determinants of managerial ownership and the link between ownership and performance. Journal of Financial Economics, vol. 53, pp. 353-384.

10. Iavorskyi M. 2013. The impact of capital structure on firm performance: evidence from Ukraine. MA thesis. Kyiv School of Economics.

11. Jayati S. and Sarkar S. 2000. Large shareholder activism in corporate governance in developing countries: evidence from India. International Review of Finance, vol. 1, no. 3, pp.161-194.

12. Jensen M.C. and Meckling W.H. 1976. Theory of the firm: managerial behavior, agency costs and ownership structure. Journal of Financial Economics, vol. 3, no. 4, pp. 305-360.

13. Jensen M. 1986. Agency cost of free cash flow, corporate finance, and takeovers. American Economic Review, vol. 76, no. 2, pp. 323-329.

14. Kokoreva M. and Stepanova A. 2012. Financial architecture and corporate performance: evidence from Russia. Journal Corporate Finance Research, vol. 2, no. 22, pp. 34-44.

15. Majumdar S.K. and Chhibber P. 1999. Capital structure and performance: evidence from a transition economy on an aspect of corporate governance. Public Choice, vol. 98, no. 3, pp. 287-305.

16. Margaritis D. and Psillaki M. 2007. Capital structure and firm efficiency. Journal of Business Finance \& Accounting, vol. 34, no. 9-10, pp. 1447-1469.

17. Margaritis D. and Psillaki M. 2010. Capital structure, equity ownership and firm performance. Journal of Banking \& Finance, vol. 34, no. 3, pp. 621-632.

18. McConnell J.J. and Servaes H. 1995. Equity ownership and the two faces of debt. Journal of Financial Economics, vol.39, no.1, 131-157.

19. Mehran H. 1995. Executive compensation structure, ownership, and firm performance. Journal of Financial Economics, vol. 38, no. 2, pp. 163-184.

20. Michaelas N., Chittenden, F. and Poutziouris P. 1999. Financial policy and capital structure choice in U.K. SMEs: empirical evidence from company panel data. Small Business Economics, vol. 12, pp.113-130.

21. Modigliani F. and Miller M.H. 1958. The cost of capital, corporation finance and the theory of investment. The American Economic Review, vol. 48, no. 3, pp. 261-297. 
22. Morck R., Shleifer A. and Vishny R.W. 1988. Characteristics of targets of hostile and friendly takeovers. Corporate takeovers: causes and consequences. University of Chicago Press, pp. 101-136.

23. Nickell S., Nicolitsas D. and Dryden N. 1997. What makes firms perform well? European Economic Review, vol. 41, no. 3, pp. 783-796.

24. Nickell S. and Nicolitsas D. 1999. How does financial pressure affect firms? European Economic Review, vol. 43, no. 8, pp. 1435-1456.

25. Onaolapo A.A. and Kajola S.O. 2010. Capital structure and firm performance: evidence from Nigeria. European Journal of Economics, Finance and Administrative Sciences, vol. 25, pp. 70-82.

26. Poyry S. and Maury B. 2009. Influential ownership and capital structure. Working paper series. Hanken School of Economics (Helsinki, Finland). 35 p.

27. Pushner G.M. 1995. Equity ownership structure, leverage, and productivity: empirical evidence from Japan. Pacific-Basin Finance Journal, vol. 3, no. 2, pp. 241-255.

28. Rajan R.G. and Zingales L. 1995. What do we know about capital structure? Some evidence from international data. Journal of Finance, vol. 50, no. 5, pp. 1421-1460.

29. Salim M. and Yadav R. 2012. Capital structure and firm performance: evidence from Malaysian listed companies. Social and Behavioral Sciences, vol. 65, pp. 156-166.

30. Schmukler S.L. and Vesperoni E. 2006. Financial globalization and debt maturity in emerging economies. Journal of Development Economics, vol. 79, no. 1, pp. 183--207.

31. Schneider Fr. 2003. The size and development of the shadow economies and shadow economy labor force of 22 transition and 21 OECD countries: What do we really know? The Informal Economy in the EU Access Countries: Size, Scope, Trends and Challenges to the Process of EU Enlargement, Center for Study of Democracy, pp. 23-61.

32. Smith A.J. 1990. Corporate ownership structure and performance: the case of management buyouts. Journal of Financial Economics, vol.27, no.1, pp. 143-164. 